\title{
The relationship of economic and useful traits in the Ural type cows of the black-and-white breed
}

\author{
O.V. Gorelik ${ }^{1, *}$, J.S. Pavlova ${ }^{1}$, T.Yu. Shvechikhina ${ }^{2}$, O.A. Arapova ${ }^{1}$, and L.F. Ponomareva ${ }^{3}$ \\ ${ }^{1}$ Ural State Agricultural University, Karl Liebknecht str., 42, 620075 Yekaterinburg, Russian \\ Federation \\ ${ }^{2}$ South Ural State Agrarian University, pr. Lenina, 75, 454080 Chelyabinsk, Chelyabinsk region, \\ Russian Federation \\ ${ }^{3}$ K.G. Razumovsky Moscow State University of technologies and management (The First Cossack \\ University), Zemlyanoy Val, 73, 109004 Moscow, Russian Federation
}

\begin{abstract}
In the Sverdlovsk region, holsteinized black-and-white cattle of the Ural type are bred. All cows have high productivity indicators; the best milk yields are distinguished by the animals of the Vis Back Ideal line, which surpass their peers by 99 (Reflection Sovering line) and $1477 \mathrm{~kg}$ (Montwick Chieftain line) or by $0.9-13.7 \%$. In the second case, the difference is significant at $\mathrm{P} \leq 0.01$. According to the FMF in milk, higher values were observed in cows of the Montwick Chieftain line $-4.03 \pm 0.003 \%$. They significantly surpass cows from other lines by $0.04-0.07 \%$ at $\mathrm{P} \leq 0.01$, which did not affect the output of nutrients with milk. There is a stable high correlation between cow milk yield and milk fat yield with milk. The correlation coefficients approach one. A negative correlation was found between milk yield and fat mass fraction, which ranged from low (-0.03, Montwick Chieftain line) to medium ( -0.34 , Vis Back Ideal line). The average positive relationship between the fat mass fraction in milk and the amount of milk fat was found in cows of the lines of the Reflection Sovering and Vis Back Ideal
\end{abstract}

\section{Introduction}

Providing the world's population with full-fledged food of anumal origin is one of the most important tasks of animal husbandry development around the world [1-7]. Such products are milk and its derivatives. The increase in its production is inextricably linked to an increase in cow productivity and milk quality improvement, which has a significant impact on the quality of finished dairy products [8-18]. All over the world, dairy cattle are used to produce milk. Currently, the main population of dairy cattle in the world is represented by animals of the best world breed - Holstein and its crossbreeds, which differ in economic and useful qualities depending on the natural and climatic, ecological and fodder conditions and the gene pool of breed resources of the breeding zone [19-20]. Thus, in the Sverdlovsk region, a large array of holsteinized black-and-white cattle of the Ural type has been created, the

\footnotetext{
${ }^{*}$ Corresponding author: olgao205en@yandex.ru
} 
improvement of which continues, including through the further use of purebred Holstein bulls-producers of the best lines [21-23]. The assessment of the relationship between the economic and useful traits of cows of holsteinized black-and-white cattle of different lines is relevant and has practical significance, especially in the conditions of increasing the blood of the Holstein breed.

The purpose of the work was to assess the relationship of economic and useful traits of cows of holsteinized black-and-white cattle of different lines.

\section{Materials and Methods}

The research was carried out in one of the pedigree breeding units for breeding of holstinized black-and-white cattle of the Ural type in the Sverdlovsk region. For the study, 3 groups of cows were identified after 2 lactation: group 1 - cows of the Reflection Sovering line 198998; group 2 - Vis Back Ideal 1013415; group 3 - Montwick Chieftain 95679. Data of zootechnical and breeding records of the Selex program, protocols of control milking and evaluation of milk quality indicators were used. The correlation coefficients between economic and useful characteristics were calculated.

\section{Results and discussion}

Currently, the farm uses the daughters of bulls-producers belonging to 6 lines: 3 Holstein, 1 - Dutch and 2 - black-and-white breed of the Ural offspring. The most interesting are the descendants of the bulls-producers of Holstein lines - Reflection Sovering 198998, Montwick Chieftain 95679, Vis Back Ideal 1013415, as they represent the main livestock of the herd. Data on milk productivity indicators are presented in figure 1.

$$
\text { Milk yield for } 305 \text { days of lactation, } \mathrm{kg} \quad \square \mathrm{MJ}, \% \quad \square \mathrm{MDB}, \%
$$

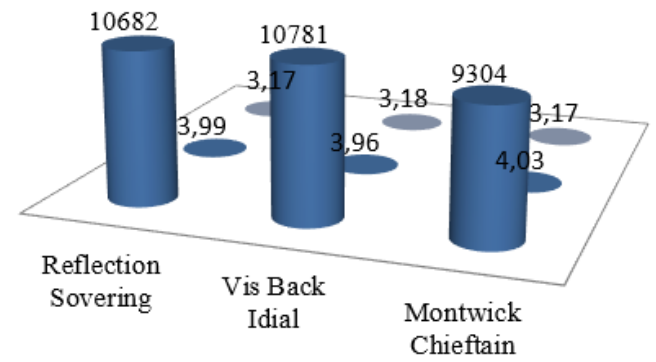

Fig. 1. Milk yield and quality indicators of cow milk.

The figure clearly shows that all cows have high productivity indicators, the best milk yields are distinguished by animals of the Vis Back Ideal line, which exceed their peers by 99 (Reflection Sovering line) and $1477 \mathrm{~kg}$ (Montwick Chieftain line) or by $0.9-13.7 \%$. In the second case, the difference is significant at $\mathrm{P} \leq 0.01$. According to milk quality indicators, namely, the FMF in milk, higher indicators were noted in the cows of the Montwick Chieftain line $-4.03 \pm 0.003 \%$. According to this indicator, they significantly surpass cows from other lines by $0.04-0.07 \%$ at $\mathrm{P} \leq 0.01$, which did not affect the output of nutrients with milk (figure 2). 


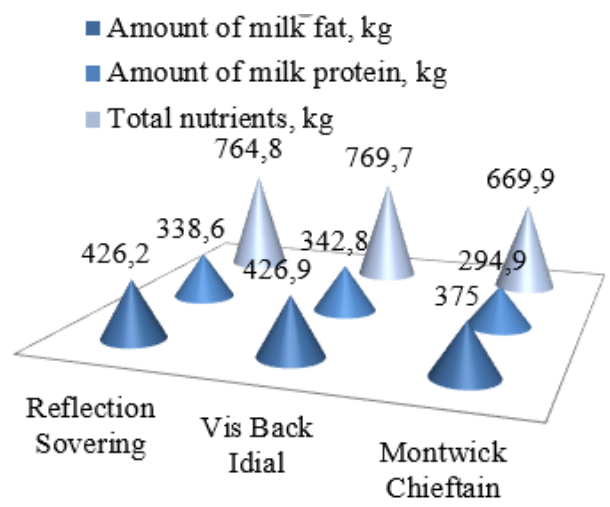

Fig. 2. The output of the nutrients of milk, $\mathrm{kg}$.

More nutrients were obtained from the milk of cows of the Vis Back Ideal line, which is primarily due to the greater influence on this indicator of milk yield for 305 days of lactation, which is confirmed by the high correlation coefficient between milk yield and the amount of fat. At the same time, a negative correlation was established between milk yield and fat mass fraction in milk (figure 3).

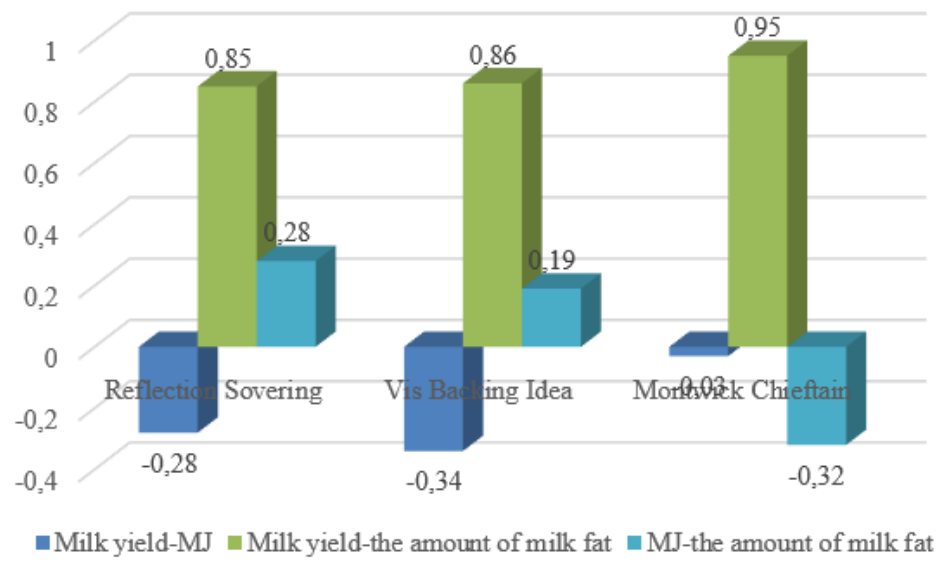

Fig. 3. Correlation coefficients of productive features.

The figure clearly shows that there is a stable high relationship between the milk yield of cows and the output of milk fat with milk. The correlation coefficients approach one or $100 \%$. A negative correlation was found between milk yield and fat mass fraction, which ranged from low (-0.03, Montwick Chieftain line) to medium (-0.34, Vis Back Ideal line). The average positive relationship between fat mass fraction in milk and amount of milk fat was established in cows of Reflection Sovering and Vis Back Ideal lines, which shows that with an increase in FMF in milk, there is an increase in the output of milk fat with milk during lactation. In animals of the Montwick Chieftain line, the correlation coefficient had an average negative value. This confirms once again that FMF in milk has no or insignificant effect on the output of nutrients in milk.

During evaluation of economic-useful characteristics much attention is paid to the reproductive ability of cows, which is evaluated both by the age of the first insemination, which allows to judge the intensity of repair heifers growing, and the duration of service and calving intervals, as well as by the coefficient of reproductive ability (CRA) (Table 1). 
Table 1. Indicators of the reproductive capacity of cows

\begin{tabular}{|c|c|c|c|c|}
\hline Line & \multirow{2}{*}{$\begin{array}{c}\text { Age of first } \\
\text { insemination, } \\
\text { months }\end{array}$} & \multicolumn{2}{|c|}{ Duration of the period, days of } & \multirow{2}{*}{ CRA } \\
\cline { 3 - 4 } & $13.6 \pm 0.15$ & $179.7 \pm 14.17$ & $466.7 \pm 15.25$ & 0.78 \\
\hline $\begin{array}{c}\text { Reflection } \\
\text { Sovering }\end{array}$ & $14.1 \pm 0.23$ & $183.2 \pm 11.94$ & $470.6 \pm 16.29$ & 0.78 \\
\hline Vis Backing Idea & $15.3 \pm 0.33$ & $116.4 \pm 14.28$ & $403.1 \pm 12.36$ & 0.91 \\
\hline $\begin{array}{c}\text { Montwick } \\
\text { Chieftain }\end{array}$ & & & calving & \\
\hline
\end{tabular}

From the data in the table, it can be seen that there are certain problems with reproduction in the herd, as evidenced by the low indicators of the coefficient of reproductive ability, which should be at least 0.95 . The best reproduction rates were observed in the Montwick Chieftain cows, where the duration of the service and calving interval was shorter and the CRC was higher -0.91 .

The relationship between the reproductive capacity of cows and their productivity is of interest. The correlation coefficients between the milk yield - service period and the age of the first insemination are shown in figure 3.

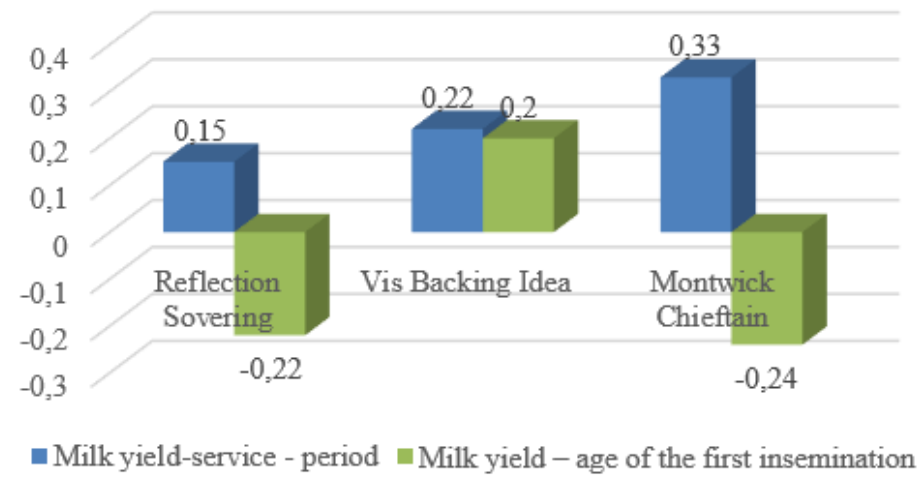

Fig. 4. Correlation coefficients of reproductive abilities with milk yield of cows.

When carrying out selection and breeding work with the herd, it is necessary to take into account that an increase in the duration of the service period leads to an increase in milk yield, but a decrease in the reproductive functions of cows.

\section{Discussion}

The breeding of holsteinized black-and-white cattle of the Ural type along the Holstein lines allows to obtain animals with high breeding value, having a high genetic potential of dairy productivity. Animals of different lines differ from each other in economic and useful characteristics that are interrelated. The correlation coefficients between the traits in cows of different lines differ. Similar studies were conducted by V.S. Mymrin, O.G. Loretts [7], I.V. Tkachenko, V.F. Gridin, S.L. Gridina [10], S.L. Gridina, V.F. Gridin, O.I. Leshonok [8].

\section{Conclusion}

All animals, regardless of their linear origin, had a high genetic potential for productivity. The relationship of economic and useful characteristics among themselves differed 
depending on the linear affiliation of cows. The cows of the Holstein lines of the Ural type of holsteinized black-and-white cattle have certain problems with reproduction.

\section{References}

1. O. Gorelik, M. Rebezov, A. Gorelik, S. Harlap, I. Dolmatova, T. Zaitseva, N. Maksimuk, N. Fedoseeva and N. Novikova, International Journal of Innovative Technology and Exploring Engineering, 8(7), 559 (2019)

2. O. Gorelik et al, International Journal of Pharmaceutical Research (2019)

3. O. Gorelik et al, Annual Research \& Review in Biology, 18(4), 1 (2017)

4. O. Gorelik et al, AIP Conference Proceedings, 2207, 020012 (2020)

5. A. Belookov, O. Belookova, V. Zhuravel, S. Gritsenko, I. Bobyleva, E. Ermolova, S. Ermolov, Y. Matrosova, M. Rebezov, E. Ponomarev, International Journal of Engineering and Advanced Technology, 8(4), 1058 (2019)

6. F. Khaziakhmetov et al, Research Journal of Pharmaceutical, Biological and Chemical Sciences, 9(3), 866 (2018)

7. F. Khaziakhmetov, A. Khabirov, M. Rebezov, A. Basharov, I. Ziangulov, E. Okuskhanova, International Journal of Veterinary Science, 7(4), 178 (2018)

8. F. Smolnikova, Z. Moldabayeva, M. Klychkova, O. Gorelik, R. Khaybrakhmanov, I. Mironova, A. Kalimullin, G. Latypova, International Journal of Innovative Technology and Exploring Engineering, 8 (7), 670 (2019)

9. N. Chernopolskaya, N. Gavrilova, I. Karapetyan, International Journal of Pharmaceutical Research, Jan-Mar 2019, 11(1), 545 (2019)

10. N. Chernopolskaya, N. Gavrilova, M. Rebezov, S. Harlap, A. Nigmatyanov, G. Peshcherov, T. Bychkova, K. Vlasova, I. Karapetyan, International Journal of Pharmaceutical Research, 11(1), 545 (2019)

11. N. Gavrilova, N. Chernopolskaya, E. Molyboga, L. Ponomareva, International Journal of Innovative Technology and Exploring Engineering, 8(6), 642 (2019)

12. N. Gavrilova, N. Chernopolskaya, E. Schetinina, I. Suyazova, S. Safronov, V. Ivanova, E. Sultanova, Journal of Critical Reviews, 7(4), 233 (2020)

13. N. Gavrilova, N. Chernopolskaya, M. Rebezov, D. Moisejkina, I. Dolmatova, I. Mironova, G. Peshcherov, O. Gorelik and M. Derkho, International Journal of Recent Technology and Engineering, 8(2), 2718 (2019)

14. M. Temerbayeva et al, Annual Research \& Review in Biology, 23(6), 1 (2018)

15. O.V. Gorelik et al, IOP Conf. Ser.: Earth Environ. Sci., 548, 082009 (2020)

16. O.V. Gorelik et al, IOP Conf. Ser.: Earth Environ. Sci. (2020)

17. F. Smolnikova, S. Toleubekova, M. Temerbayeva, E. Cherkasova, O.K. Gorelik, S. Harlap, M. Derkho, M. Rebezov, I. Penkova, Journal of Pharmaceutical, Biological and Chemical Sciences, 9(3), 1003 (2018)

18. N. Kuramshina, M. Rebezov, E. Kuramshin, L. Tretyak, G. Topuria, D. Kulikov, A. Evtushenko, S. Harlap, E. Okuskhanova, International Journal of Pharmaceutical Research, 11(1), 1301 (2019)

19. E. Skvortsov, O. Bykova, V. Mymrin, E. Skvortsova, O. Neverova, V. Nabokov, V. Kosilov, The Turkish Online Journal of Design Art and Communication, 8, 291 (2018)

20. V. Mymrin, O. Loretts, Proceedings of the International Scientific and Practical Conference (ISPC 2019) Advances in Intelligent Systems Research, 511 (2019) 
21. S. Gridina, V. Gridin, O. Leshonok, Advances in Engineering Research, 253 (2018)

22. O. Chechenikhina, O. Loretts, O. Bykova, E. Shatskikh, V. Gridin, L. Topuriya, International Journal of Advanced Biotechnology and Research, 9(1), 587 (2018)

23. I. Tkachenko, V. Gridin, S. Gridina, Results of researches federal state scientific institution "ural research institute for agri-culture" on identification of interrelation efficiency cows of the ural type with the immune status : 085-090 (2016) 